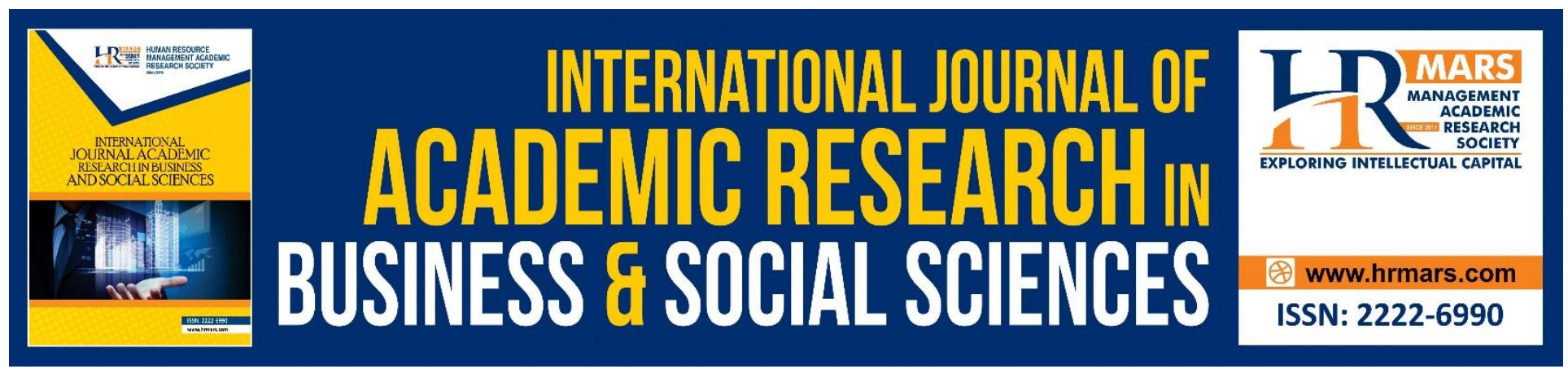

\title{
Underground Space Ownership in Malaysia: Defining the Rights
}

Farah Zaini, Aminah Mohsin

To Link this Article: http://dx.doi.org/10.6007/IJARBSS/v11-i14/8565

DOI:10.6007/IJARBSS/v11-i14/8565

Received: 11 December 2020, Revised: 03 January 2021, Accepted: 14 January 2021

Published Online: 30 January 2021

In-Text Citation: (Zaini \& Mohsin, 2021)

To Cite this Article: Zaini, F., \& Mohsin, A. (2021). Underground Space Ownership in Malaysia: Defining the Rights. International Journal Academic Research in Business and Social Sciences, 11(14), 191-198.

Copyright: (C) 2021 The Author(s)

Published by Human Resource Management Academic Research Society (www.hrmars.com)

This article is published under the Creative Commons Attribution (CC BY 4.0) license. Anyone may reproduce, distribute, translate and create derivative works of this article (for both commercial and non-commercial purposes), subject to full attribution to the original publication and authors. The full terms of this license may be seen

at: http://creativecommons.org/licences/by/4.0/legalcode

Special Issue: Contemporary Business and Humanities Landscape Towards Sustainability, 2021, Pg. 191 - 198 http://hrmars.com/index.php/pages/detail/IJARBSS JOURNAL HOMEPAGE

Full Terms \& Conditions of access and use can be found at http://hrmars.com/index.php/pages/detail/publication-ethics 


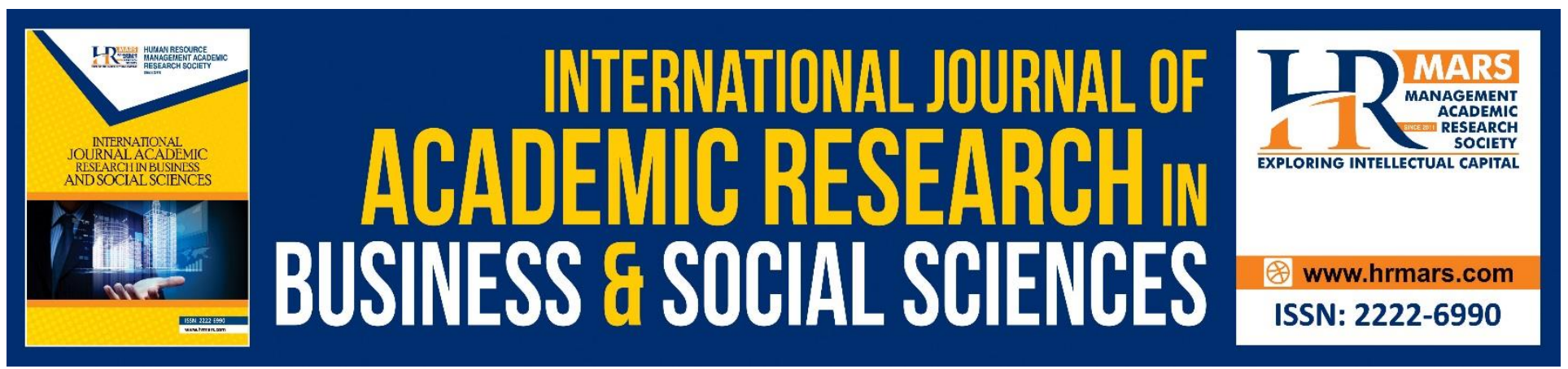

\title{
Underground Space Ownership in Malaysia: Defining the Rights
}

\author{
Farah Zaini, \\ Faculty of Social Sciences and Humanities, Universiti Malaysia Sarawak, Kota Samarahan, Sarawak \\ Email: zfarah@unimas.my \\ Aminah Mohsin \\ Faculty of Built Environment and Surveying, Universiti Teknologi Malaysia, 81310 Skudai, Johor
}

\begin{abstract}
Underground space development is one of the development alternatives taken by many countries including Malaysia. Therefore, the National Land Code 1965 (NLC 1965) was amended to insert Part Five (A) for underground space disposal. However, the legislation is still ambiguous and has raised many arguments between the landowners and the developers. The land ownership has become the major issues in developing the underground space. It create conflicts when underground space to be developed by the different landowners on the surface. Even though the legislation is there, the mechanism of implementation is absent. Hence, this study was undertaken to understand the concept of surface landowner towards his underground space and underground space ownership. This study is a purely qualitative study and interviews were conducted with four selected respondents who were involved in underground space development in Malaysia by using the semi-structured interview questions to get their views and opinions to support this study. The obtained data were then analyzed descriptively. The findings have shown that two important elements need to be emphasized in underground space ownership, which is the land rights and depth. However, to further assist the underground space development in the future, Malaysia must consider revising the concept of underground space tenure to help in explaining and differentiate the tenure and rights held by the surface landowner, the underground space owner and also the developer individually.
\end{abstract}

Keywords: Underground Space, Land Ownership, Property Rights, Qualitative Study

\section{Introduction}

Malaysia's experience in developing the underground space is not new. The record has shown several previous underground space developments such as the commercial development of the Merdeka Square. The underground space development in Malaysia involved mostly either the State or Federal land and even the private land, in case it was developed by the landowner himself. However, the 
issue of land owner's rights to the underground space was raised in 2011 during the MRT development namely for the underground station and has opened the eyes of many parties that the underground space can now be developed not only under the state-owned land but also under the private land involving different owners.

\section{Underground Space Development in Malaysia}

According to the National Land Code 1965, Section 92A, underground space can be defined as land that lies below the surface of the earth. In the perspective of land use, underground space can be designed and developed based on the purpose of development and they are closed or separated by a layer/level. The function of the separation is to differentiate the activities of the surface from the underground. It cannot be classified as an underground space development if the level is not closed or separated because there is no separation between the surface and the underground to differentiate the activities.

Therefore, the underground space can be recognized is a space below the ground level, whether on a flat surface, slope, hard strata or rock. Referring to Part VA, NLC 1965 and Circular of the Director General of Lands and Mines No. 1/2008, underground space can be developed either involving the activities connected with the surface development or as an independent function of development. If the underground space is disposed to any person or an agency for development, it is called a stratum where the function of the development must be different from the features of the surface development.

There are four resources in developing underground space; namely space, water, materials and energy (Parriaux et al., 2007). According to Hunt et al. (2016), planning for underground space should be done based on local contexts, depending on priorities and conditions. Not all type of development are suitable to be built underground because it depends on the development pattern of the city, and which one need to be prioritize first (Huanqing et al., 2015). Besides, preservation of heritage buildings and existing development are among the consideration to develop the underground space (Broere, 2015). By choosing the underground space for development, many aspects need to be considered to ensure the development does not complicate the development now and future; among the noteworthy is the legal consideration (Stones \& Yoong, 2016). Why do we need to focus on the legal aspects? This is because the legal restrictions are one of the obstacles to the development and use of the underground space (Barker, 1991; Sterling, 1996; Xu \& Zhu, 2013; Farah et al., 2017). Normally, the framework for surface land development is available and clear, but not in the case of the underground space.

No matter what the type of development below is, the surface landowners are the main concern since they have the rights to their land as endorsed in Section 44 (1) (a) of the NLC 1965, which include the exclusive right and enjoyment of the land as is reasonable. While, for the underground space ownership or known as the stratum title, the rights of the owner are subject to Section 92 B (3) (a) (b), of the NLC 1965. Regarding underground development, the surface landowners must be protected not only in terms of the legal land rights but also the safety and psychology of those living at the surface during the on-going underground construction (Qiao et al., 2019; Haghani et al., 2014). Hence, both the surface and the underground space owners must be clear as to their rights over the land. 


\section{Methodology}

This study is a purely qualitative study. The data collection was done through in-depth interview and the descriptive analysis is required to prescribe the secondary data. The interviews were carried out in this study to gain clear information on the status of land ownership of underground space development in Malaysia.

The non-probability sampling was used to select the respondents. The sampling of interviewees was done through purposive sampling, which means a specific focus group of individuals can respond to the interview questions regarding the legal aspects in underground space development. The interviews were conducted by using the semi-structured interview questions with the focus respondents that were selected and identified from those directly involved in the underground space development in Malaysia. The interviews involved four (4) respondents from various agencies that have the background of land administration and development. The respondents are indicated by code R1, R2, R3 and R4.

\section{Land Ownership Concept of Underground Space: The Analysis}

The land ownership for underground space refers to two conditions. First is the extension of underground space ownership of the surface landowner; and second is the separate underground space ownership or stratum title. The purpose of the analysis was to identify the rights held by the surface landowners over their underground space and the rights of the underground space owners. Although in the National Land Code 1965, Section 44 (1) (a) (b) (c) states the bundle of rights of landowners, the rights must be clearly explained to ensure that they understand the rights that lie under the land title. Even though the NLC 1965 allows the underground space to be disposed of, it has never been implemented by way of land alienation.

\section{The Extension of Underground Space Ownership (Surface Landowner)}

Section 44 (1), of the NLC 1965, explains that the landowners can utilize their underground land to the extent of reasonably necessary also, the alienated land has the right to support from land adjacent to the original condition, and other natural rights. Hence, when the underground space development is carried out, how is the surface land able to have the right to support naturally by the underground space? Therefore, what are the rights held by the landowners towards the underground space and how can we categorize them? This analysis helps us understand how far the term "reasonable" applies in the context of the extension of ownership. It needs to be clearly defined and explained so that the respective landowner can enjoy the land without guilt. The views of the respondents are important because they are the parties responsible for making the policy and its implementation in the underground space development in Malaysia.

According to R1, the term "reasonable" here refers to lawful use. Lawful use means to utilize the land-based on the land category, the express conditions and the restrictions as stated in the land title. Therefore, the landowners have the rights to the land beneath and are entitled to use it as far as needed subject to the lawful use. At the same time, the surface land in its natural state must have the right to the support from the underground space, if it does not violate the laws that have been predetermined.

In the opinion of R2, the landowners think that the maxim is applied to land ownership because no one can interpret how far the term "reasonable" applies. In this context, R2 referred to the Land 
Acquisition Act 1960. When the alienated land is acquired, the calculation of compensation does not refer to the existing land development but the possible development of the respective land. Hence, referring to "possible", the land may be or will be developed for commercial or industry, for instance. Therefore, the compensation will be awarded based on the potential development and maximum value of the surrounding area. If we compare the term "possible" to "reasonable", for instance, if the development is for residential use, then 20 meters for airspace and 20 meters for underground space can be considered as for reasonable use. However, is it reasonable for the surrounding area? So, it is very difficult to determine the context of reasonable. Thus, it is better if we specify the term "reasonable" based on the proposed development and how far the landowner wants to enjoy the underground space because the surface land also has the natural rights to the support from any of the adjacent land.

R4 also supported the opinion of R2 where he agreed that the reasonable use will depend on the need of the surface land development. This is because he opined that logically, the landowner will not utilize his underground space until 100 meters downwards if the surface development is only of four-storey. Thus, it depends on the need of the development above, which determines the depth required for its support. In conclusion, when the surface landowner utilizes his land as is reasonable, hence he has the right to full support from the adjacent land as to include the underground space as in its natural state. If there are damages to the building above during the underground construction, then the developer should bear the liability.

$\mathrm{R3}$, on the other hand, opined that the reasonable use is the right of the landowner over his land; and he can construct a structure as high as possible through the seven layers of the sky, also the seven layers of the earth. That is the right held by the landowner. However, of course, the right is subjected to some restrictions and limitations by the laws. For example, if he applies for a development order to construct the building, he has to get the development approval concerning the Town and Country Planning Act (Act 172), or if it is in the Federal Territory, then he has to get the approval from the Local Authority based on the Federal Territory Planning Act 1982.

Furthermore, if the development is to be carried out where the land is in the vicinity of the airport, then it is subject to the Civil Aviation Act, which limits the height of the structure. Besides, if the developer wishes to carry out the underground development, the engineering and technical aspect of safety to the existing building (if it is already a developed land) should be considered. This is all because the surface land has the right to support from the underground space. If underground space development causes damage to the existing buildings, then the surface landowner has the rights to claim for compensation. Therefore, the right (reasonable use) is subject to various laws, if it does not break the laws or the respective guidelines.

\section{The Underground Space Ownership (Stratum Title)}

The National Land Code 1965 was amended through the insertion of Part Five (A) that allows the disposal of underground space and the issuance of the stratum title. However, as pointed out by R1 in the interview, the provision has never been implemented for the underground space disposal since the insertion in 2008. The analysis of the issues in underground space development showed that Part 
Five (A) of the NLC 1965 is lacking at some point and needs to be revised to assist the implementation of the development. Thus, the opinions of the respondents are important to identify the key elements that must be considered in underground space alienations. Every element must be clearly explained to avoid misinterpretation. This is because the underground space alienation is in the 3-Dimensional form which requires additional information compared to the current land alienation.

In this matter, R1 responded two key elements are important for underground space alienation. The first element is regarding the rights of the surface landowner over the underground space and that of the underground space owner. The provisions state that there are two situations which allow the alienation of the underground space under private land. One situation is where the alienated land has had the depth specified. In this case, any eligible person can apply for the stratum title to the underground space.

The other situation is where the depth of the alienated land has not been specified. For this case, only the surface landowner is eligible to apply for the stratum title. This is because when the depth is not specified, the surface landowner will have the rights to his underground space and there is no limitation to enjoy the land as long within a lawful use. However, if the surface landowner applies for the stratum title, automatically the land under the stratum will become the State land. The effect is the landowner is surrendering his rights under Section 44 (1) (a), of NLC 1965, to the State where the land now has a limitation of depth.

While the second element that needs to be put forward is the depth. According to R1, there is a reason why the current practice of land alienation has not specified the depth. This is because if the depth is specified, the landowner would not be able to enjoy his land, and the rights under Section 44 (1), of the NLC 1965 will be denied. But, looking at the current issue where there is an argument between the landowners and the developer to develop the underground space makes us believe that it is important to specify the depth in the land alienation. However, R1 also believed that even though the depth is important for the underground space alienation, it should not be specifically stated as to how deep the land is possessed by the landowner. The landowner has the right to enjoy his land. Besides, the development can be placed in another area, for instance, under the State land. However, for the stratum title, the exact volume of land to be alienated needs to be specified. This is because the height, breadth and length are the important aspects to form the volume needed for the stratum title.

R2 has also suggesting the key elements namely the rights of the landowner and the reasonable depth in land ownership (surface and underground space) that are needed in underground space alienation. If the surface landowner's rights are subject to Section 44 (1), of the NLC 1965, then the same goes for the underground space owners. There should be no differences in land rights for both the landowners. The only difference is that one concerns the surface and the other the underground. If we refer to the definition of land under Section 5, of the NLC 1965, the underground space is included as a part of the land. Hence, the stratum owner also holds the same land rights as the surface landowner which includes the rights of land dealings. In the perspective of the depth of ownership, R2 opined that during the land alienation the depth must be specified depending on the need of the development, the soil profile and the development on the surface land. It is important to ensure the 
surface structures are not disturbed by the underground construction and the smooth process of underground space development.

R3 had supported the opinion of R2 where he also opined that the underground space owner also holds the same rights as the surface landowner. This means that the stratum owner also has the right to enjoy the land as necessary and of course based on the depth limitation. Apart from that, he also has the right to the support from the adjacent land in the natural state and of access to the surface. At the same time, R3 also affirmed that depth is the key element in the underground space alienation. In Section 92 (B) (3), of the NLC 1965, it is stated that the State Authority may determine the depth of the underground space upon alienation. R3 did not agree to the use of the word 'may' concerning 'determine the depth'; instead the State Authority shall determine the depth by replacing 'may' with the word 'must'. Otherwise, there will be a dispute. For example, the KLCC's landowner had applied for underground space alienation, so evidently, the State Authority must specify the height for the underground space alienation and the volume as well. This is because if the height is not determined, there might be a dispute between the surface landowner and the new underground space owner in the future.

Meanwhile, according to R4, since the depth is the important element in underground space alienation, it is essential for Malaysia now to have 3-Dimensional (3D) information of the land. It should include the information on the land alienation, land use zoning and type of development proposed. Together with the advancement in technology, it is possible to develop the system for the 3D information in the land alienation system. R4 also opined that both the landowners (surface and underground) will need to accept the nature of dependence between them in the development. For instance, the surface development is using the underground space for the support of the structure; while the underground space development is in the form of a volume and surely needs the land above it to support the development work. Thus, during the underground space alienation, the rights of the surface and the underground space owners must be justified to ensure both developments are not disturbed.

\section{Conclusion}

It can be concluded that the current legislation in Malaysia is adequate to assist the underground space development in the aspects of legal consideration. This study agreed that the existing law should remain as it is. However, if there is a need to enhance the underground space utilization in the future, then, the law or the circular can be amended as necessary. We must consider revising the underground space tenure to ensure that every single detail regarding the land alienation is made clear. This will help to explain and differentiate the tenure and the rights held by each of the party concerned; the surface landowner, the underground space owner and the future underground space developer.

\section{References}

\section{Reference to a Journal Publication}

Barker, M. (1991). Legal and Administrative Issues in Underground Space Use: A Preliminary Survey of ITA Member Nations. Tunnelling and Underground Space Technology (Vol. 6). 
Broere, W. (2015). Urban underground space: Solving the problems of today' s cities q. Tunnelling and Underground Space Technology, 10-13. https://doi.org/10.1016/j.tust.2015.11.012

Huanqing, L., Xiaozhao, L., \& Chee, S. (2015). An integrated strategy for sustainable development of the urban underground: From strategic, economic and societal aspects. Tunnelling and Underground Space Technology. https://doi.org/10.1016/j.tust.2015.12.011

Hunt, D. V. L., Makana, L. O., Jefferson, I., \& Rogers, C. D. F. (2016). Liveable cities and urban underground space. Tunnelling and Underground Space Technology Incorporating Trenchless Technology Research, 55, 8-20. https://doi.org/10.1016/j.tust.2015.11.015

Parriaux, A., Blunier, P., Maire, P., Tacher, L. (2007). The DEEP CITY project: a global concept for a sustainable urban underground management. In: Paper Presented the 11th ACUUS

Qiao, Y.-K., Peng, F.-L., Sabri, S., \& Rajabifard, A. (2019). Socio-environmental Costs of Underground Space Use for Urban Sustainability. Sustainable Cities and Society, 101757.

Ronka, K., Ritola, J., \& Rauhala, K. (1998). Underground Space in Land-Use Planning. Tunnelling and Underground Space Technology, 13(1), 39-49.

Sterling, R. L. (1996). Going Under to Stay on Top, Revisited : Results of a Colloquium on Underground Space Utilization. Tunnelling and Underground Space Technology, 11(3), 263-270.

Stones, P., \& Yoong, T. (2016). Underground space development key planning factors. Procedia Engineering, 165, 343-354. https://doi.org/10.1016/j.proeng.2016.11.709

Xu, S., \& Zhu, X. (2013). Research on Current Legislation for Urban. In Advances in Underground Space Development (pp. 663-671). Singapore: Research Publishing.

\section{Reference to acts}

Malaysia. (1965). National Land Code 1965.

JKPTG. (2008). Circular of the Director General of Lands and Mines No. 1/2008 